Vacher, G. ; Niculita-Hirzel, H. ; Roger, T. Immune responses to airborne fungi and non-invasive airway diseases. Seminars in Immunopathology, 37(2) :83-96, 2015.

\begin{tabular}{|l|l|}
\hline Postprint version & Final draft post-refereeing \\
\hline Journal website & http://link.springer.com/journal/281 \\
\hline Pubmed link & http://www.ncbi.nlm.nih.gov/pubmed/25502371 \\
\hline DOI & $\underline{\text { DOI:10.1007/s00281-014-0471-3 }}$ \\
\hline
\end{tabular}




\title{
Immune responses to airborne fungi and non-invasive airway diseases
}

\author{
Gaëlle Vacher $^{1}$, Hélène Niculita-Hirzel ${ }^{1 * \S}$, Thierry Roger ${ }^{2 * \S}$ \\ ${ }^{1}$ Service of Occupational Hygiene, Institute for Work and Health, University of Lausanne and Geneva, Epalinges- \\ Lausanne, Switzerland \\ ${ }^{2}$ Infectious Diseases Service, Centre Hospitalier Universitaire Vaudois (CHUV) and University of Lausanne \\ (UNIL), Lausanne, Switzerland \\ *Co-corresponding authors: \\ Thierry Roger, Infectious Diseases Service, CLE/D04/407, Chemin des Boveresses 155, CH-1066 Epalinges, \\ Switzerland \\ Thierry.Roger@chuv.ch ; +4121314 1038
}

Hélène Niculita-Hirzel, Service of Occupational Hygiene, Institute for Work and Health, University of Lausanne and Geneva, Biopole 1 Building, Corniche 2, CH-1066 Epalinges-Lausanne, Switzerland.

Helene.Hirzel@hospvd.ch ; +4121314 7147

$\S$ Hélène Niculita-Hirzel and Thierry Roger joint senior authors

Short title: Immune responses to airborne fungi

\author{
Abstract word count: 175 \\ Body text word count: 5849 \\ Number of references: 165 \\ Number of Tables: 2
}




\begin{abstract}
Inhalation of fungal particles is a ubiquitous way of exposure to microorganisms during human life, however this exposure may promote or exacerbate respiratory diseases only in particular exposure conditions and human genetic background. Depending on the fungal species and form, fungal particles can induce symptoms in the lung by acting as irritants, aeroallergens or pathogens causing infection. Some thermophilic species, can even act in all these three ways (e.g. Aspergillus, Penicillium), mesophilic species being only involved in allergic and/or non-allergic airway diseases (e.g. Cladosporium, Alternaria, Fusarium). The goal of the present review is to present the current knowledge on the interaction between airborne fungal particles and the host immune system, to illustrate the differences of immune sensing of different fungal species and to emphasize the importance of conducting research on non-conventional mesophilic fungal species. Indeed, the diversity of fungal species we inhale and the complexity of their composition have a direct impact on fungal particle recognition and immune system decision to tolerate or respond to those particles, eventually leading to collateral damages promoting airway pathologies.
\end{abstract}

Key words: Mesophilic fungi, Immunity, Inflammation, Lung, Airway disease 
Fungal particles are ubiquitous in outdoor as well as in built environment air. Their growth is greatly dependent on humidity, temperature and availability of nutritive substrates. Fungal species can be present in aerosols in different forms: hyphae fragments, spores or yeast. Their number vary from thousand in the outdoor air [1], to forty in the indoor air [2]. The species composition in the air varies depending on the season [3] and on the presence of particular conditions of fungal growth (water-damage, waste, grain etc.). However, allergic and non-allergic respiratory diseases have been associated only to particular aerosols compositions [4-6] or to the presence of one dominant fungal species in the inhaled air [7]. Noteworthy, it was recently proposed that this is not the exposure to a particular fungal species that favors the development of respiratory pathologies, but the low diversity of the fungal species present in the inhaled air [8]. Yet, a large number of thermophilic as well as mesophilic fungal species have been incriminated in airway pathologies. The factors that favor growth of fungal species have been identified outdoor [7] and in the built environment [9], such as the occupational positions most likely at risk (manipulation of plant or animal derived products). The mechanisms underlying the development of allergic and non-allergic pathologies induced or exacerbated by fungi have been mostly explored for thermophilic species, rarely for mesophilic species. The goal of this review is to make a state of the art on the early events of host responses which impact on the resistance (restricting fungal burden) or tolerance (limiting collateral damages caused by the immune response) to fungi and to illustrate to which airway pathologies the disruption of host-fungus relationship may lead. We will first describe the coordinated action of airway resident cells to sense the dynamic structure of the fungal cell wall, made of polysaccharides ( $>80 \%$ ) and proteins, as well as fungal derived cytoplasmic and secreted compounds. Second, we will present the mechanisms involving fungi in the development of airway allergic disorders including allergic asthma, allergic bronchopulmonary aspergillosis (ABPA) and mycosis (ABPM), allergic fungal rhinosinusitis (AFRS) and hypersensitivity pneumonitis (HP) and airway non-allergic disorders such as chronic bronchitis, organic dust toxic syndrome and chronic mycotoxicosis. Of note, we will not discuss about chronic obstructive pulmonary disease (COPD) since no convincing association between COPD and airborne fungi has been reported despite the fact that 15 to $20 \%$ of non-smokers have an occupational exposure etiology and that the exposure to organic dust has been incriminated for some of them [10-12]. Finally, we will briefly discuss the genetic variants favoring the development of non-invasive fungal airway pathologies.

\section{Airway immune response to fungal compounds}

\subsection{Processing of fungal particles in the airways}

Inhaled fungal particles deposit in different areas of the respiratory tract depending on their size, shape and aggregation with other substances. Large particles (over $5 \mu \mathrm{m}$ ) end in the nasopharyngeal region, whereas smaller particles may reach lung alveoli. Mucociliary clearance is the very first innate defense mechanism of the lung against the particles reaching the lung alveoli [13]. Cilia located along the airway walls provide a motive force for clearing microorganisms and toxic substances trapped in the mucus secreted by goblet cells. Moreover, mucus 
contains an array of molecules with microbiocidal activity or that help neutralizing pathogens, among which $\beta$ defensins, lyzosyme, lactoferrin, mucin, secretory IgA and surfactants.

The immune response to fungi is influenced by fungal species, fungus form (spore, hyphae or yeast), fungus-derived products (such as mycotoxins and allergens), co-inhalation of fungus with other substances and host genetic background. The respiratory tract is a complex structure made of multiple structural epithelial cell types broadly classified into three categories (basal, ciliated and secretory cells) and infiltrated by leukocytes [14]. Besides phagocytic cells such as alveolar macrophages and dendritic cells (DCs) that reside in the airways or sense the airway lumen, epithelial cells and possibly mesenchymal cells play an active role in the initial events driving pulmonary immune responses. The cytokines and chemokines released following fungal contact by resident airway cells stimulate the recruitment and instruct innate and adaptive cells, among which neutrophils, eosinophils, basophils, mast cells, $\mathrm{T}$ cells and $\mathrm{B}$ cells. Other cells such as the recently identified lineage-negative innate lymphoid cells (ILCs) of subgroup 2 (ILC2) are central to fungal-induced allergic inflammation due to the production of interleukin (IL)-5 and IL-13 at early stage of allergen recognition [15, 16].

DCs are permanently trafficking from lungs to draining lymph nodes, a path presumably activated by subtle maturation signals provided by the local flora at steady state and strongly amplified in inflammatory conditions during which the cytokines released by the stroma or epithelial cells instruct DCs $[17,18]$. DCs are particularly well equipped to decipher the fine structure of fungi, and the extreme plasticity of their response shapes the development of naïve CD4+ T cells into Th1, Th2 or Th17 cells that differentially affect antifungal responses [19]. For example, DCs exposed to Eurotium amstelodami or Wallemi sebi, two filamentous fungi involved in HP, induce a Th1 polarized pathogenic response [20], whereas DCs exposed to Alternaria alternata, a common allergenic fungi responsible of asthma, trigger a potent Th2 skewed immune response [21].

The differentiation of Th1, Th2 and Th17 cells is triggered by IL-12 and interferon (IFN) $\gamma$, IL-2 and IL-4 and IL-6, TGF $\beta$, IL-21 and IL-23, respectively. Th1 responses are characterized by the production of IL-2 and IFN $\gamma$, which promote protective immunity against fungal infection through activation of phagocytes, antigen presentation by antigen presenting cells and production of opsonizing antibodies. IL-4, IL-5, IL-9, IL-10, IL-13, IL-25 and amphiregulin are the main drivers of Th2 cell responses that inhibit Th1 cell responses and promote alternative activation of macrophages, production of immunoglobulin (Ig) E, eosinophilia and mast cell growth resulting in decreased fungal clearance and favoring the development of fungal allergic responses. Th17 cells, characterized by the production of IL-17A, IL-17F, IL-21, IL-22, granulocyte-macrophage colony-stimulating factor (GM-CSF) and CC-chemokine ligand (CCL) 20, have been identified more recently as an additional subpopulation of CD4+ T cells involved in host defenses against extracellular microorganisms among which fungi [22, 23]. Th17 responses facilitate fungal clearance through the mobilization of neutrophils and the production of defensins. Th17 responses have also been implicated in the development of a number of autoimmune pathologies and in airway allergic diseases such as allergic rhinitis (AR) and chronic rhinosinusitis (CRS) [24]. 
The immune response to fungi has to be tightly regulated to prevent inflammation-mediated collateral damage and maintain lung immune homeostasis. Pulmonary stromal cells promote transforming growth factor $\beta$ (TGF $\beta$ )dependent generation of tolerogenic DCs that contribute to suppress T-cell proliferation through prostaglandin E2 (PGE2) and induce the generation of regulatory (Treg) cells [25]. Treg cells produce high amounts of IL-10 and TGF $\beta$ that help limiting immunopathology, which in return may facilitate fungal persistence.

\subsection{Pathogen-associated molecular patterns and pattern-recognition receptors}

The fungal cell wall is mostly composed of polysaccharides (80-90\%) and proteins, mostly glycoproteins. Pathogenassociated molecular patterns (PAMPs) expressed by fungi are sensed by epithelial cells and sentinel phagocytic cells of the airways through pattern-recognition receptors (PRRs). The principal fungal PAMPs - $\beta$-glucans (especially $\beta 1,3$ and $\beta 1,6$ glucans), chitin ( $\beta 1,4$-linked polymer of $N$-acetyl glucosamine) and mannans - are present in most aerosolized fungi (all Ascomycetes and Basidiomycetes). Other fungal PAMPs recognized by innate immune cells are $\alpha$-glucans, galactomannans, xylomannans and chitosan, a deacetylated derivative of chitin [26, 27], which may be expressed by particular fungal taxa. Whereas $\alpha$-glucans compose the gel-like polymer of Ascomycetes and Basidiomycetes, galactomannans are found in Ascomycetes (principally Aspergillus, but also Penicillium and few other species) and xylomannans in Basidiomycetes (e.g. Cryptococcus). Therefore, the composition of the cell wall varies significantly between fungal species [28].

The immune response to fungal PAMPs is modulated according to fungal PAMPs distribution at the surface of fungal particles, their size, shape and linkage to other components. Pathogenic fungi have developed strategies to avoid immune recognition, for example Cryptococcus neoformans that bears a capsule, and dormant conidia of Aspergillus fumigatus that are covered by an immunologically inert hydrophobic rodlet layer [29]. Moreover, the fungal cell wall is a dynamic structure uneven during cell cycle and morphological transition. $\beta 1$,3-glucans are exposed on conidia but masked on hyphae of Candida albicans. By masking immunogenic PAMPs, fungi circumvent inflammatory responses, favoring fungal adaptation and opportunism [19].

The main PRRs involved in the sensing of fungal PAMPS are C-type lectin receptors (CLRs, such as dectin-1, dectin-2, mincle, DC-SIGN, the mannose receptor, the mannose binding lectin and galectin-3), Toll-like receptors (TLRs, especially TLR2, TLR4 and TLR9) and Nod-like receptors (NLRs) [19, 30-32]. The cooperative recognition of fungal PAMPs by several PRRs is required for optimal anti-fungal responses [33-35]. Most of our knowledge about PRRs and pathways involved in host responses to fungi derives from studies using mostly the thermophilic species C. albicans and A. fumigatus [19, 26, 27, 30-32, 36] and can only be extrapolated to mesophilic species when these species are sharing similar cell wall characteristics and cytoplasmic composition.

$\beta 1,3$ glucans are the major components of fungal cell wall. Immune cells sense $\beta$-glucans primarily through dectin- 1 that is expressed at high levels by myeloid cells, yet with possibly different outcomes. For example, $\beta$-glucans trigger much higher TNF production by DCs than by macrophages [37]. TLR2, complement receptor 3 (CR3) and scavenger receptors (CD5, CD36 and SCARF1) have also been described to detect $\beta$-glucans. Ligand binding to 
dectin-1 engages Syk-CARD9 and Raf-1 dependent signalling pathways that relay activation of the canonical (cRel) and non-canonical (RelB) nuclear factor (NF)-кB pathways, and stimulates endocytosis and phagocytosis, the respiratory burst, the production of cytokines and chemokines, the differentiation and maturation of DCs and the development of effector $\mathrm{T}$ and $\mathrm{B}$ cells responses [38-40]. The panel of cytokines produced following dectin-1 triggering drives antifungal Th1 and Th17 responses. Shaping the development of Th17 responses requires the interaction of dectin- 1 with TLRs, which amplifies the production of IL-1 $\beta$, IL-6 and IL-23 and down-regulates the production of IL-12 [41]. Interestingly, dectin-1 promotes pro-IL-1 $\beta$ processing via activation of both the canonical, caspase-1 dependent, NLRP3 (NLR pyrin domain containing 3) inflammasome and a noncanonical caspase-8 inflammasome [42, 43]. The density of $\beta 1,3$ glucans at the cell surface varies between fungal species and between fungal forms (yeast or hyphae). Mold-induced asthma in mice repeatedly exposed to Aspergillus versicolor and Cladosporium cladosporioides - fungal species with respectively high and low surface $\beta$-glucans - revealed that $A$. versicolor induces a dectin-1 dependent Th17 response with neutrophilia and low airway hyper-responsiveness (AHR) whereas C. cladosporioides induces a dectin-1 independent Th2 response with eosinophilia and strong AHR $[44,45]$. These data suggest that fungi that expose low levels of $\beta$-glucans at their surface are more susceptible to induce allergic Th2 polarized immune responses. In agreement, $\beta$-glucans from Wallemia sebi and Eurotium amstelodami, fungal species associated to HP development, promote Th1 polarized responses by DCs [20]. Along with a primordial role for dectin-1 in antifungal defences, mutations in dectin-1 and CARD9 have been associated with fungal infections [46-48].

Chitin is the second-most abundant polysaccharide in fungal cell wall. Chitin is not surface-exposed, but chitin fragments are released and stimulate host cells following phagocytosis and digestion of fungal particles by lysozyme and chitinase/chitinase-like proteins (C/CLPs) that are constitutively expressed by epithelial lung cells and macrophages [49]. Moreover, chitin content and exposure at the cell surface may increase upon antifungal therapy with echinocandins, and therefore affect host immune responses [50, 51]. Experimental and clinical studies have associated dysregulated expression of C/CLPs with Th2 inflammation and asthma development [52]. Like-minded, intrapulmonary administration of chitin into mice induced a macrophage-dependent recruitment of IL-4 expressing eosinophils and basophils [53]. Interestingly, while both chitin and chitosan are phagocytosed by macrophages, only chitosan activates the NLRP3 inflammasome and IL-1 $\beta$ secretion [54]. How the host senses and responds to chitin remains to be fully elucidated. Chitin particles promote not only Th2 responses, but also Th1 as well as Th17 responses [52]. These paradoxical findings likely arise from the usage of chitin preparations differing in origin (commercially available chitin is usually extracted from crab/shrimp shells), purity and particle size. Whereas large chitin fragments are immunologically inert, chitin particles of 40-70 $\mu \mathrm{m}$ stimulate tumor necrosis factor (TNF) through dectin-1 and TLR2 while chitin particles below $40 \mu \mathrm{m}$ induce TNF and IL-10 through dectin-1, the mannose receptor and TLR2 in macrophages [55]. Yet, a recent study using ultra-pure fungal-derived chitin of 1-10 $\mu \mathrm{m}$, a size likely to be relevant for host responses, showed that low concentrations of chitin stimulate IL-10 production while high concentrations of chitin induce predominantly TNF [56]. Intracellular delivery of chitin by 
the mannose receptor was preceding chitin sensing by TLR9 and NOD2. Thus, one can postulate that protection against Aspergillus-driven acute allergic disease afforded by the administration of CpG (a TLR9 agonist) into mice might result from binding competition between CpG and chitin to TLR9 [56, 57]. Additional receptors expressed by myeloid cells possibly involved in chitin/chitosan recognition encompass the C-type lectins galectin-3 and RegIII $\gamma$, FIBCD1 and NKR-P1 [49].

Mannans are $\alpha$-linked polymers of mannose covalently attached to fungal cell wall mannoproteins through ester linkage (O-linked) or amine bond (N-linked). Mannans are recognized by the mannose receptor (CD206), dectin-2, dectin-3, DC-SIGN (CD209), TLR2, TLR4 and possibly mincle [27, 32, 34, 36, 58]. While CLRs recognize Nbranched mannans, TLR4 senses O-branched mannans [33]. TLR4 and TLR2 recognize glucuronoxylomannans from C. neoformans and phospholipomannan from C. albicans, respectively [59, 60]. The mannose receptor is predominantly expressed by macrophages and DCs as part of the endocytic pathway. The mannose receptor senses several fungi and mediates, in collaboration with the TLR2/dectin-1 pathway, the release of a number of cytokines among which IL-17 [61]. Dectin-2, expressed by myeloid cells, was the first PRR shown to induce proinflammatory cytokine expression in response to fungal hyphae [62, 63]. Indeed, dectin-2 senses $\alpha$-mannans and induces Th17 responses [64, 65]. Recently, dectin-2 was shown to form with dectin-3 a heterodimeric complex to recognize $\alpha$ mannans and mediate host defenses to C. albicans infection [58]. DC-SIGN expressed on DCs, macrophages and endothelial cells favors the uptake and phagocytosis of C. albicans and A. fumigatus conidia, which is inhibited by Aspergillus-derived galactomannans [66-68]. The sensing of C. albicans through DC-SIGN modulates co-signaling via TLRs and stimulates the production of IL-10, suggesting an important role of mannans in regulating DC response [67]. Mincle is predominantly expressed on activated macrophages and detects mannose derivatives or Nacetyl-glucosamine from C. albicans [69] as well as glycolipids from Malassezia, an opportunistic skin fungal pathogen [70, 71]. Interestingly, co-engagement of mincle and dectin-1 by Fonsecaea monophora, an etiologic agent of chromoblastomycosis, blocks IL-12 production and redirects dectin-1 mediated antifungal Th1 polarization to a Th2 response [72].

All these data indicate that fungi trigger multiple PRRs of the same or different families to modulate host immune response to their own benefit. Conversely, cross-regulation of cytokine production by immune cells through the engagement of multiple PRRs fine-tunes host defense mechanisms, allowing resistance and tolerance to fungi.

\subsection{Fungal allergens}

Fungi express multiple kinds of allergens - cytoplasmic and structural components released upon cell (auto) lysis and secreted metabolic products. In contrast to fungal cell wall components, allergens are mostly fungal species or family specific. Fungal allergens elicit hypersensitivity reactions not only of type I (IgE-mediated), but also of type II, type III (IgG-mediated) and type IV (delayed type hypersensitivity) that may act together to mediate pathogenesis. Yet, fungi are poorly studied in the field of molecular allergology, and the role of fungal allergens in airway diseases is poorly characterized [73]. Fungal allergenic proteins, secreted mainly during spore germination 
and mycelia growth, can be classified into five chief categories: proteases, glycosidases, components of protein synthesis/secretion, proteins of the stress response and proteins of gluconeogenesis. Fungal proteases have been characterized in some fungal species relevant for allergic respiratory diseases, such as A. fumigatus (Asp f5, f6, f11, f13, f15, f18) and Trichophyton rubrum (Tri r4, Tri t4). Fungal proteases play a particularly important role in allergen sensitization, and represent one of the initiator of lung allergic responses [7, 74]. Indeed, proteases initiate Th2-skewed lung allergenic responses by inducing thymic stromal lymphopoietin (TSLP) secretion by lung epithelial cells [75]. Proteases may have also an adjuvant effect on allergenic properties of other proteins [7]. Proteases facilitate antigen access to host cells by direct receptor-specific interaction involving protease-activated receptor type-2 (PAR-2) with epithelial cells or by damaging epithelial cells allowing access to underlying cells. As an example, A. alternata, A. fumigatus and Cladosporium herbarum proteases not only stimulate cytokine secretion, but also promote epithelial cell barrier disruption [76, 77]. A. alternata extracts also activate eosinophils in a PAR-2dependent manner, favoring allergen sensitization and Th2-biased inflammatory responses [78, 79].

\subsection{Fungal metabolites}

\subsubsection{Non-volatiles low molecular weight metabolites: mycotoxins}

Mycotoxins are secondary metabolites produced by a large number of Ascomycetes at particular stages of fungal growth and in particular environments. They are rarely specific of one fungal species and they are most frequently produced by close related fungal species. However, within the same species, some strains are mycotoxins producers and others not. As they are present within fungal particles, mycotoxins can be inhaled at the same time as fungal particles. Mycotoxins produced by Aspergillus, Penicillium, Stachybotrys, Trichoderma and Chaetomium species have been detected indoor [80], whereas those produced by Aspergillus, Fusarium or Penicillium species have been found in the aerosols of occupational places where plant derived materiel is manipulated. Only the mycotoxins produced by Aspergillus, Fusarium and Penicillium species (Table 1) have been classified as carcinogenic in humans and animals [81]. In addition to their toxic effects, mycotoxins may also display important immunomodulatory and immunotoxic effects depending on toxin concentration, toxin co-administration and the ratio between each toxin. Aflatoxin and ochratoxin suppress cell-mediated immunity [82]. Gliotoxin, patulin and citrinin impair IFN $\gamma$ production [83] and decrease intracellular glutathione in DCs, which is responsible for decreased IL-12 secretion and skewing toward Th2 immune responses [84]. Trichothecene mycotoxins (T-2 toxin, nivalenol, deoxynivalenol, 3-acetyldeoxynivalenol, fusarenon-X) have strong immunotoxicity as these toxins target mitotic tissues with important immune functions such as the bone marrow, intestinal mucosa, lymph nodes and thymus. While trichothecene mycotoxins are usually considered immunosuppressive, one of them, deoxynivalenol, may either stimulate or suppress immune functions depending on the dose and exposure conditions [85]. The estrogenic mycotoxin zearalenone (ZEA) and its metabolites bind the estrogenic receptor to inhibit immune functions such as cytokine production (TNF, IL-1 $\beta$, IL-6, IL-8 and IFN $\gamma$ ) and T cell proliferation [86, 87]. Fumonisin B1 have animal species-specific effects, thus the immunosuppressive activities attributed to this mycotoxin in pigs are not necessarily extrapolated to humans [82, 88]. 


\subsubsection{Volatiles low molecular weight metabolites: microbial volatile organic components}

All molds produce volatile organic components (VOCs). More than 200 different microbial VOCs (MVOCs) have been characterized in fungi, mostly alcohols, aldehydes, amines, chlorinated hydrocarbons, ketones, terpenes, aromatic and sulphuric compounds [89, 90]. MVOCs are often responsible of strong/unpleasant odors. Fungi have unique MVOC profiles depending on their development stage, size and substrate for development. For example, 1,3dimethoxybenzene and 2,4-pentandione are produced by A. versicolor and A. fumigatus but not Penicillium expansum, Penicillium chrysogenum, Aspergillus niger and C. cladosporoides growing on wall paper [91]. Chronic exposure to MVOCs may lead to short as well as long term adverse health effects. In the airways of sensitive people, MVOCs induce irritation and inflammation [89, 90]. In agreement, two prevailing MVOCs, $\alpha$-pinene and 1-octen-3ol, stimulate cytokine and nitric oxide production by immune cells (neutrophils and alveolar macrophages; hemocytes in Drosophila) [92]. Of note, some fungi produce both mycotoxins and MVOCs (Aspergillus and Penicillium spp.; Table 1), which may further affect the sensitive host. Yet, clearly much more work is required to fully appreciate the immunomodulatry properties of mycotoxins and MVOCs and their impact in human airway diseases.

\section{Allergic responses after fungal particle exposure}

\subsection{Allergic asthma}

Asthma is a multifactorial chronic and persistent pulmonary inflammation with airway obstruction, breathlessness, mucus hyper-secretion and airway hyper-responsiveness, clinically ranging from intermittent to severe forms [93, 94]. Inflammation leads to bronchoconstriction, vasodilatation and hyperplasia of bronchial smooth muscles. The prevalence of mold allergy to Alternaria, Aspergillus, Candida, Cladosporium and Penicillium is much higher in atopics and asthmatics when compared to the general population [73]. Moreover, numerous epidemiological studies have associated chronic exposure to fungi with asthma symptoms in children and asthma exacerbation in adults [4, 6, 80, 95, 96]. The most frequent fungal species associated with allergic asthma are Alternaria, Aspergillus, Aureobasidium, Cladosporium, Epicoccum, Helminthosporium and Penicillium [97]. Bronchial provocation tests with spores in non-occupational mild asthmatic adult patients suggest that a minimal dose of $9.10^{4}$ spores of $A$. alternata and $6.10^{4}$ spores of Penicillium spp. is required to induce clinical symptoms [98]. To distinguish fungal sensitization from fungal involvement in asthma development and/or exacerbation, allergen-specific IgE serum levels should be systematically tittered for a large panel of fungal allergens, together with a systemic analysis of the dominant fungal species to which asthmatic subjects are exposed.

Etiologic agents associated with asthma of fungal origin are heterogeneous, and a role for fungal chitin and proteases as triggered of asthmatic reactions has been proposed [7]. As discussed earlier, fungi with low or unavailable cell surface $\beta$-glucans favor Th2 polarized immune response related to an asthmatic phenotype. In addition, mycotoxins such as gliotoxin and patulin impact on DCs to stimulate Th2 responses and trigger asthma- 
like symptoms in a model of acute asthma in mice [84]. The underlying mechanisms involved in allergic airway diseases are not fully understood, but our knowledge has improved markedly over the last years. Allergens activate airway epithelial cells and DCs to produce IL-1, IL-25, IL-33, TSLP, GM-CSF, eicosanoids and danger signals that are involved in the expansion and activation of type 2 innate lymphoid cells (ILC2) and activate DCs migration to lymph nodes where they instruct Th2 cell differentiation with the help of IL-4 secreting basophils [99, 100]. Lung ILC2 are a major source of IL-5, IL-9 and IL-13 that, with other cytokines from the local milieu, induce eosinophilia, mast cell mobilization and IgE and mucus production. Of note, ILC2 have just been reported to be increased in the blood of asthmatic patients [101], but not yet in asthmatic lung tissues contrary to IL-25, IL-33 and TSLP. Asthma has long been considered as a Th2-mediated pathology, but recently Th17 cells have been pointed out as important effector cells in asthma, especially severe steroid-resistant asthma characterized by IL-17 production and neutrophilia [102]. Th17 differentiation is dictated by DCs secreting IL-1 $\beta$ and IL-23, and associated with the expression of IL-17 and IL-22, a member of the IL-10 family that can mediate both pro-inflammatory and anti-inflammatory effects [103]. Overall, the phenotypic heterogeneity of asthma might be related to $\mathrm{T}$ cell response polarization. Yet, the underlying mechanisms responsible for dominant Th2, Th17 or Th2/Th17 mixed responses during allergic asthma are not well understood.

\subsection{Allergic bronchopulmonary aspergillosis (ABPA) and allergic bronchopulmonary mycosis (ABPM)}

ABPA refers to an exaggerated immune response to fungal colonization of the lower airways by A. fumigatus whereas ABPM refers to allergic bronchopulmonary diseases due to species other than Aspergillus. The principal etiological agents of ABPM reported worldwide are C. albicans, Bipolaris spp., Schizophyllum commune and Curvularia spp. [104]. ABPM/ABPA prevalence in the general population is unknown. ABPA prevalence in patients having mucociliary clearance impairment such as asthmatic and cystic fibrosis patients is around $1-2 \%$ and $2-15 \%$, respectively $[105,106]$. The prevalence of ABPM in asthmatic and cystic fibrosis patients is unknown, yet ABPM occurs more frequently than ABPA in patients without asthma [104]. The exposure level of spores triggering ABPA/ABPM is not clearly defined. Due to impaired mucociliary clearance, fungal particles from thermophilic species might remain in the lower respiratory tract long enough to germinate and to breach the epithelial barrier. This may lead to pro-inflammatory cytokine release, activation of antigen presentation cells and skewed Th2 responses with mast cell proliferation and eosinophilia [104, 107]. ABPA/ABPM are characterized by severe asthma initially associated with type I IgE-mediated hypersensitivity, subsequently with type III IgG-mediated hypersensitivity [104]. Type IV hypersensitivity is also present in ABPA. Fungal specific IgE, IgA and IgG can be detected in bronchoalveolar lavage and serum of patients [104]. The diagnosis of ABPA/ABPM is not trivial, and the identification of genetic risk factors should improve the recognition of high-risk patients (Table 2). It seems also important to enlarge the panel of fungi tested for ABPM diagnosis.

\subsection{Allergic fungal rhinosinusitis (AFRS)}


Although the definition of AFRS is controversial, AFRS can be described as a subset of chronic rhinosinusitis (CRS) in immunocompetent patients due to fungal colonization of a sinus with impaired mucociliary clearance [108110]. AFRS patients generally suffer from a unilateral chronic sinus infection with fungal allergy, nasal airway obstruction and congestion, purulent rhinorrhoea, postnasal drainage and headache [109]. Eosinophilic mucus, fungal detection in sinus, presence of nasal polypsis and type I IgE-mediated hypersensitivity are characteristics of AFRS patients [111]. Symptoms associated with AFRS are related to luminal degranulation of mucosal eosinophils and release of cytotoxic proteins (Charcot-Leyden crystals) responsible of tissue damages [112]. Aspergillus species were expected to be a common causative agent of AFRS, however Bipolaris spicifera, Curvularia lunata, A. alternata, Cladosporium spp. and Trichoderma longibrachiatum are commonly incriminated in AFRS [109, 113115]. Unexplained cases of CRS should be systematically screened for AFRS diagnostic since allergic fungal sinusitis represent 6 to $9 \%$ of the CRS requiring surgery [116].

The prevalence of AFRS is higher in warm geographical regions with a high humidity rate (from 0 to $23 \%$ in USA) [117]. AFRS prevalence ranges from 5 to $10 \%$ in CRS patients, and AFRS patients can represent more than $87 \%$ of the patients with fungal rhinosinusitis (FRS) [118]. Controversy on the classification of CRS and difficulties of differential diagnosis between CRS subcategories may explain the absence of a fair description of the immunological cascade underlying AFRS pathogenesis. AFRS is characterized by mixed type I, III and IV hypersensitivity reactions, and T cell-derived IL-5 and IL-13 that activate eosinophils to release toxic factors for the epithelium in the sinus cavity. Interestingly enough, CRS was the first human pathology in which the accumulation of ILC2 in inflamed tissues was clearly shown [119]. Although allergic rhinitis is classically viewed as a Th2 skewed pathology, recent studies have shown the up-regulation of Th17 specific parameters in local mucosa and peripheral blood of patients, which correlated with eosinophilia and symptom severity [24].

\subsection{Hypersensitivity pneumonitis (HP)}

HP, also called extrinsic allergic alveolitis, is a generic term defining a non IgE-mediated bronchial and alveolar inflammation caused by an exaggerated immunological response to a variety of organic particles. The most common antigens implicated in HP are bird proteins and bacteria; however fungi are also frequently incriminated in HP development in particular working populations and in the general population in Japan [120]. Acute HP patients suffer from fever, chills, dyspnea, dry cough, headache, malaise, interstitial mononuclear cell infiltration, nonnecrotizing poorly formed granulomas, cellular bronchiolitis with spontaneous resolution after cessation of antigen exposure. Chronic HP patients also have chronic interstitial inflammation and alveolar destruction associated with dense fibrosis in $41 \%$ of the cases [3, 98]. The prevalence of HP in the general population is low (around 0.9 cases per 100'000/year in the United Kingdom) but much more elevated in populations chronically exposed to high amounts of fungal particles such as farmer's population [3, 121, 122]. Provocation tests suggest that repeated exposure to $10^{7}$ to $4.10^{9}$ spores $/ \mathrm{m}^{3}$ is required to set off fungal-related HP [98]. 
HP subtypes are classically defined based on the nature of inhaled antigens, the most common being the bird fancier's lung and the farmer's lung. The panel of fungi involved in HP is large (for example Aspergillus, Alternaria, Aureobasidium, Cladosporium, Cryptococcus, Epicoccum, Eurotium amstelodami, Fusarium, Lichtheimia , Paecilomyces, Penicillium, Trichosporon and Wallemia), reflecting the population and geographical area of interest $[3,123]$.

HP is a mix of type III and type IV allergic reaction. The immune response is characterized by neutrophilic and lymphocytic infiltration in the lower respiratory tract with macrophage and T cell-derived cytokines. In acute and subacute clinical forms, cell-mediated immunopathogenesis has been associated with Th1 responses [124]. However, Th2 mechanisms have been described in chronic HP with a fibrotic phenotype [125]. In addition, mouse models of Stachybotrys chartarum-induced HP suggest that Th17 responses are also involved in HP pathogenesis [126].

\section{Non-allergic disease to fungal compounds}

\subsection{Chronic bronchitis}

Chronic bronchitis refers to a recurrent, often irreversible, inflammation of the bronchial mucous membrane with hypersecretion of mucus and hyperplasia of goblet cells and submucosal glands. Its prevalence in the general population is around $2.5 \%$ but can vary from 5 to $40 \%$ among workers depending on the level of exposure to antigens [98]. Chronic bronchitis occurs after long-term exposure to large concentrations of fungal spores ( $2.10^{9}$ to $14.10^{9}$ spores $/ \mathrm{m}^{3}$ over 1 hour) resulting in irreversible damages to the lung. Predominant clinical symptoms are a persistent wet cough and breathing complications [98]. A. fumigatus and Penicillium frequentans (present on cork) are associated with chronic bronchitis $[127,128]$. Our understanding of the pathophysiology of chronic bronchitis is rudimentary.

\subsection{Organic dust toxic syndrome (ODTS)}

ODTS is also known as toxic alveolitis, pulmonary mycotoxicosis, silo unloader's (filler's) syndrome, atypical farmer's lung or grain fever. ODTS is an acute, non-allergic sickness characterized by flu-like symptoms associated with a local acute toxic effect due to exposure to very high amounts of organic dust [9]. In most cases, symptoms (cough, fever, breathlessness) develop 4 to 8 hours after exposure. Symptoms last generally less than 24 hours but may persist 5-7 days [9]. The prevalence of ODTS is around 36\% among workers exposed to organic dusts; it is unknown in the general population [129]. Due to the increased protection of agricultural workers, ODTS cases are expected to decrease in the future. ODTS is related to inhalation of mycotoxins during mold contaminated grain handling (coffee, pepper, wheat) or animal (e.g. poultry) related activities. The principal fungal species incriminated are A. fumigatus, Aspergillus nidulans and Penicillium spp. [130]. The exact role of mycotoxins in ODTS is not clearly defined, yet adverse events are more related to chronic exposure to toxicogenic fungi than non-toxicogenic fungi [131]. Organic dust inhalation results in massive neutrophil recruitment to the lungs, following chemotactic 
signals provided by lung epithelial cells and macrophages. Pyrogenic cytokines are likely contributing to fever and other inflammatory parameters of ODTS [132].

\subsection{Chronic mycotoxicosis and other pathologies associated with fungal metabolites}

Water-damage building syndrome, also called "mold-related illness", has been associated to the exposure to molds in water-damaged building. Main symptoms are fatigue, headache with dermatological, gastrointestinal as well as reproductive, rheumatologic and immune related symptoms [133]. A wide range of molds is found in water-damage buildings, among which Penicillium, Aspergilus, Chaetomium, Acremonium, Ulocladium, Cladosporium, Mucor, Trichoderma, Alternaria, Sporothrix, Rhodotorula, Rhizopus, Stachybotrys, Calcarisporium, Scopulariopsis and Fusarium spp. to cite the most representative ones [134].

Living and/or working in a water-damage building has been associated with the presence of toxicogenic fungi and of their mycotoxins (especially aflatoxin, ochratoxin and trichothecenes) in nasal wash and with an increased concentration of mycotoxins in urine $[135,136]$. Mycotoxin toxicity may be aggravated by the formation of fungal biofilm in sinus [137]. Mycotoxins have also been shown to accumulate in lungs, spleen and lymph nodes [135], as well as in placenta, umbilical cord blood and breast milk in symptomatic pregnant women, which might be responsible for side effects on fetus or new-born [138]. Despite the established deletary role of mycotoxins in animal models, epidemiological evidences struggle to establish a link between mycotoxins and respiratory health effects. Intra-tracheal instillation in rats of toxicogenic S. chartarum, a mold suspected to be the etiological agent of pulmonary hemorrhages in children due to its presence in the building and in air samples, induces lung inflammation related to the release of IL-1 $\beta$ and TNF by $\beta$-glucan-activated alveolar macrophages [139].

Since MVOCs accumulate in the air of water-damage buildings, they are suspected to participate to health adverse events. Exposure to MVOCs has been linked to symptoms such as headaches, nasal irritation, dizziness, fatigue, nausea and swelling/inflammation of the airways [140-142]. MVOCs such as 3-methylfuran were also associated with other respiratory adverse events summarized in the guidelines for indoor air quality [143].

\section{Genetic variants as risk factors of fungal non-invasive related pathologies}

Host genetic factors impact on host tolerance or resistance to microorganisms, as it is the case for its susceptibility to infection by opportunistic or non-invasive fungal infections. Both primary immune-deficiencies affecting a single gene at the individual level (monogenic inheritance) and genetic polymorphisms affecting several genes at the population level (polygenic inheritance) have been extensively studied in relation with invasive Aspergillus and Candida infections. These studies have implicated polymorphisms in numerous genes encoding for proteins involved in the whole immunological cascade activated upon fungal contact, such as PRRs, cytokines, chemokines and their receptors and signaling molecules $[144,145]$. The most reliable associations, supported by functional effects, concern polymorphisms affecting pathways triggered by dectin-1 and pentraxin-3 (PTX3), a PRR involved in host defenses against A. fumigatus [146]. Unfortunately, numerous associations may not be robust due to several 
limitations in study design [145]. This is also true for gene association studies concerning the pathologies discussed here, which moreover do not specifically incriminate fungi as the etiological agents of the studied patients apart from ABPA and AFRS. This being said, polymorphisms of human leukocyte antigen (HLA) genes have been associated with the development of allergic airway disorders (asthma, ABPA/ABPM, AFRS; Table 2). Additionally, mutations in IL4RA have been associated with Alternaria-sensitive moderate-severe asthma in children [158], whereas mutations in TLR9, CFTR, SPA2, IL4RA and IL10 genes have been reported as risk factors for ABPA [147150]. No other unambiguous or validated genetic association with allergic or non-allergic fungal airway disease has been reported.

\section{Conclusion}

Although it is well recognized that ubiquitous fungi are involved in the pathogenesis of a broad panel of allergic and non-allergic airway diseases, many issues should deserve more attention, for example the molecular characterization of fungal allergens in mesophilic fungal species, the screening for fungal allergy in relation with the identification of fungal species present in patient environment and the determination of the immunomodulatory or immunotoxic effects of mycotoxins and/or MVOCs delivered by these environmental fungal species. Moreover, the mechanisms controlling host responses to fungal particles and genetic susceptibility to respiratory pathologies induced by fungi were studied primarily in the context of fungal infections such as those promoted by C. albicans and A. fumigatus, while mesophilic species associated to the development of allergic or non-allergic airway diseases receive a much more modest attention. In depth characterization of the genetic, molecular and cellular actors involved in hostmesophilic fungus interactions, of the impact of lung microbial ecosystem on lung immunity and of the pathophysiological characteristics of patients with non-invasive airway diseases is also warranted as it would help to understand how different fungal species (and microorganisms at large) induce similar pathologies and, conversely, how the same fungal species can cause different pathologies. On the long term, answering these questions would pave the path for designing new therapeutic strategies with the aim to improve the outcome of patients suffering from life threatening airway diseases. 


\section{Acknowledgments}

This work has been financially supported by an interdisciplinary grant from the Faculty of Biology and Medicine of the University of Lausanne (Switzerland) to $\mathrm{HNH}$ and TR, the Agence Nationale de Sécurité Sanitaire de l'Alimentation, de l'Environnement et du Travail (France, grant 2011/1/087) to HNH, and by a grant from the Swiss National Science Foundation to TR (grant 320030_149511).

\section{Conflict of interest}

All the authors declare no conflict of interest.

\section{References}

1. Yamamoto N, Bibby K, Qian J, Hospodsky D, Rismani-Yazdi H et al. 2012. Particle-size distributions and seasonal diversity of allergenic and pathogenic fungi in outdoor air. ISME J 6: 1801-11

2. Vesper SJ, Varma M, Wymer LJ, Dearborn DG, Sobolewski J et al. 2004. Quantitative polymerase chain reaction analysis of fungi in dust from homes of infants who developed idiopathic pulmonary hemorrhaging. $J$ Occup Environ Med 46: 596-601

3. Selman M, Lacasse Y, Pardo A, Cormier Y. 2010. Hypersensitivity pneumonitis caused by fungi. Proc Am Thorac Soc 7: 229-36

4. Reponen T, Lockey J, Bernstein DI, Vesper SJ, Levin L et al. 2012. Infant origins of childhood asthma associated with specific molds. J Allergy Clin Immunol 130: 639-44 e5

5. Reponen T, Vesper S, Levin L, Johansson E, Ryan P et al. 2011. High environmental relative moldiness index during infancy as a predictor of asthma at 7 years of age. Ann Allergy Asthma Immunol 107: 120-6

6. Vesper S, Barnes C, Ciaccio CE, Johanns A, Kennedy K et al. 2013. Higher Environmental Relative Moldiness Index (ERMI) values measured in homes of asthmatic children in Boston, Kansas City, and San Diego. J Asthma 50: 155-61

7. Denning DW, O'Driscoll BR, Hogaboam CM, Bowyer P, Niven RM. 2006. The link between fungi and severe asthma: a summary of the evidence. The European respiratory journal 27: 615-26

| 8. Dannemiller KC, Mendell MJ, Macher JM, Kumagai K, Bradman A et al. 2014. Next-generation DNA sequencing reveals that low fungal diversity in house dust is associated with childhood asthma development. Indoor Air 24: 236-47

9. Linaker C, Smedley J. 2002. Respiratory illness in agricultural workers. Occup Med (Lond) 52: 451-9

10. Salvi SS, Barnes PJ. 2009. Chronic obstructive pulmonary disease in non-smokers. Lancet 374: $733-43$

11. Balmes J, Becklake M, Blanc P, Henneberger P, Kreiss K et al. Environmental, Occupational Health Assembly ATS. 2003. American Thoracic Society Statement: Occupational contribution to the burden of airway disease. Am J Respir Crit Care Med 167: 787-97

12. Mehta AJ, Miedinger D, Keidel D, Bettschart R, Bircher A et al. 2012. Occupational exposure to dusts, gases, and fumes and incidence of chronic obstructive pulmonary disease in the Swiss Cohort Study on Air Pollution and Lung and Heart Diseases in Adults. Am J Respir Crit Care Med 185: 1292-300

13. Hallstrand TS, Hackett TL, Altemeier WA, Matute-Bello G, Hansbro PM, Knight DA. 2014. Airway epithelial regulation of pulmonary immune homeostasis and inflammation. Clin Immunol 151: 1-15 
14. Knight DA, Holgate ST. 2003. The airway epithelium: structural and functional properties in health and disease. Respirology 8: 432-46

15. Bartemes KR, Iijima K, Kobayashi T, Kephart GM, McKenzie AN et al. 2012. IL-33-responsive lineageCD25+ CD44(hi) lymphoid cells mediate innate type 2 immunity and allergic inflammation in the lungs. $J$ Immunol 188: 1503-13

16. Walker JA, Barlow JL, McKenzie AN. 2013. Innate lymphoid cells--how did we miss them? Nat Rev Immunol 13: $75-87$

17. Hammad H, Lambrecht BN. 2007. Lung dendritic cell migration. Adv Immunol 93: 265-78

18. Maldonado RA, von Andrian UH. 2010. How tolerogenic dendritic cells induce regulatory $\mathrm{T}$ cells. $\mathrm{Adv}$ Immunol 108: 111-65

19. Romani L. 2011. Immunity to fungal infections. Nat Rev. Immunol 11: 275-88

20. Bellanger AP, Pallandre JR, Borg C, Loeffert S, Gbaguidi-Haore H et al. 2013. Human monocyte-derived dendritic cells exposed to microorganisms involved in hypersensitivity pneumonitis induce a Th1-polarized immune response. Clin Vaccine Immunol 20: 1133-42

21. Kobayashi T, Iijima K, Radhakrishnan S, Mehta V, Vassallo R et al. 2009. Asthma-related environmental fungus, Alternaria, activates dendritic cells and produces potent Th2 adjuvant activity. J Immunol 182: 2502-10

22. Zhu J, Paul WE. 2008. CD4 T cells: fates, functions, and faults. Blood 112: 1557-69

23. Gaffen SL, Jain R, Garg AV, Cua DJ. 2014. The IL-23-IL-17 immune axis: from mechanisms to therapeutic testing. Nat Rev Immunol 14: 585-600

24. Liu Y, Zeng M, Liu Z. 2014. Th17 response and its regulation in inflammatory upper airway diseases. Clin Exp Allergy

25. Li Q, Guo Z, Xu X, Xia S, Cao X. 2008. Pulmonary stromal cells induce the generation of regulatory DC attenuating T-cell-mediated lung inflammation. Eur J Immunol 38: 2751-61

26. van de Veerdonk FL, Kullberg BJ, van der Meer JW, Gow NA, Netea MG. 2008. Host-microbe interactions: innate pattern recognition of fungal pathogens. Curr Opin Microbiol 11: 305-12

27. Levitz SM. 2010. Innate recognition of fungal cell walls. PLoS Pathog 6: e1000758

28. Latge JP. 2010. Tasting the fungal cell wall. Cell Microbiol 12: 863-72

29. Aimanianda V, Bayry J, Bozza S, Kniemeyer O, Perruccio K, Elluru SR, Clavaud C, Paris S, Brakhage AA, Kaveri SV, Romani L, Latge JP. 2009. Surface hydrophobin prevents immune recognition of airborne fungal spores. Nature 460: 1117-21

30. Romani L. 2004. Immunity to fungal infections. Nature reviews. Immunology 4: 1-23

31. Sancho D, Reis e Sousa C. 2012. Signaling by myeloid C-type lectin receptors in immunity and homeostasis. Annu Rev Immunol 30: 491-529

32. Hoving JC, Wilson GJ, Brown GD. 2014. Signalling C-type lectin receptors, microbial recognition and immunity. Cell Microbiol 16: 185-94

33. Netea MG, Gow NA, Munro CA, Bates S, Collins C et al. 2006. Immune sensing of Candida albicans requires cooperative recognition of mannans and glucans by lectin and Toll-like receptors. J Clin Invest 116: 1642-50

34. Hontelez S, Sanecka A, Netea MG, van Spriel AB, Adema GJ. 2012. Molecular view on PRR cross-talk in antifungal immunity. Cell Microbiol 14: 467-74

35. Hardison SE, Brown GD. 2012. C-type lectin receptors orchestrate antifungal immunity. Nat Immunol 13: 81722

36. Drummond RA, Brown GD. 2013. Signalling C-type lectins in antimicrobial immunity. PLoS Pathog 9: e1003417

37. Goodridge HS, Wolf AJ, Underhill DM. 2009. Beta-glucan recognition by the innate immune system. Immunol Rev 230: 38-50

38. Gringhuis SI, den Dunnen J, Litjens M, van der Vlist M, Wevers B et al. 2009. Dectin-1 directs T helper cell differentiation by controlling noncanonical NF-kappaB activation through Raf-1 and Syk. Nat Immunol 10: 203-13

39. LeibundGut-Landmann S, Gross O, Robinson MJ, Osorio F, Slack EC et al. 2007. Syk- and CARD9dependent coupling of innate immunity to the induction of $\mathrm{T}$ helper cells that produce interleukin 17. Nat Immunol 8: 630-8

40. Jia XM, Tang B, Zhu LL, Liu YH, Zhao XQ et al. 2014. CARD9 mediates Dectin-1-induced ERK activation by linking Ras-GRF1 to H-Ras for antifungal immunity. $J$ Exp Med 
41. Vautier S, Sousa Mda G, Brown GD. 2010. C-type lectins, fungi and Th17 responses. Cytokine Growth Factor Rev 21: 405-12

42. Gringhuis SI, Kaptein TM, Wevers BA, Theelen B, van der Vlist M et al. 2012. Dectin-1 is an extracellular pathogen sensor for the induction and processing of IL-1beta via a noncanonical caspase-8 inflammasome. Nat Immunol 13: 246-54

43. Gross O, Poeck H, Bscheider M, Dostert C, Hannesschlager N et al. 2009. Syk kinase signalling couples to the Nlrp3 inflammasome for anti-fungal host defence. Nature 459: 433-6

44. Mintz-Cole RA, Brandt EB, Bass SA, Gibson AM, Reponen T et al. 2013. Surface availability of beta-glucans is critical determinant of host immune response to Cladosporium cladosporioides. J Allergy Clin Immunol

45. Mintz-Cole RA, Gibson AM, Bass SA, Budelsky AL, Reponen T et al. 2012. Dectin-1 and IL-17A suppress murine asthma induced by Aspergillus versicolor but not Cladosporium cladosporioides due to differences in beta-glucan surface exposure. J Immunol 189: 3609-17

46. Ferwerda B, Ferwerda G, Plantinga TS, Willment JA, van Spriel AB et al. 2009. Human dectin-1 deficiency and mucocutaneous fungal infections. $N$ Engl J Med 361: 1760-7

47. Glocker EO, Hennigs A, Nabavi M, Schaffer AA, Woellner C et al. 2009. A homozygous CARD9 mutation in a family with susceptibility to fungal infections. $N$ Engl J Med 361: 1727-35

48. Lanternier F, Cypowyj S, Picard C, Bustamante J, Lortholary O et al. 2013. Primary immunodeficiencies underlying fungal infections. Curr Opin Pediatr 25: 736-47

49. Bueter CL, Specht CA, Levitz SM. 2013. Innate sensing of chitin and chitosan. PLoS Pathog 9: e1003080

50. Walker LA, Munro CA, de Bruijn I, Lenardon MD, McKinnon A et al. 2008. Stimulation of chitin synthesis rescues Candida albicans from echinocandins. PLoS Pathog 4: e1000040

51. Fernandes C, Anjos J, Walker LA, Silva BM, Cortes L et al. 2014. Modulation of Alternaria infectoria cell wall chitin and glucan synthesis by cell wall synthase inhibitors. Antimicrob Agents Chemother 58: 2894-904

52. Lee CG, Da Silva CA, Dela Cruz CS, Ahangari F, Ma B et al. 2011. Role of chitin and chitinase/chitinase-like proteins in inflammation, tissue remodeling, and injury. Annu Rev Physiol 73: 479-501

53. Reese TA, Liang HE, Tager AM, Luster AD, Van Rooijen N et al. 2007. Chitin induces accumulation in tissue of innate immune cells associated with allergy. Nature 447: 92-6

54. Bueter CL, Lee CK, Rathinam VA, Healy GJ, Taron CH et al. 2011. Chitosan but not chitin activates the inflammasome by a mechanism dependent upon phagocytosis. J Biol Chem 286: 35447-55

55. Da Silva CA, Chalouni C, Williams A, Hartl D, Lee CG et al. 2009. Chitin is a size-dependent regulator of macrophage TNF and IL-10 production. J Immunol 182: 3573-82

56. Wagener J, Malireddi RK, Lenardon MD, Koberle M, Vautier S et al. 2014. Fungal chitin dampens inflammation through IL-10 induction mediated by NOD2 and TLR9 activation. PLoS Pathog 10: e1004050

57. Ramaprakash H, Hogaboam CM. 2010. Intranasal CpG therapy attenuated experimental fungal asthma in a TLR9-dependent and -independent manner. Int Arch Allergy Immunol 152: 98-112

58. Zhu LL, Zhao XQ, Jiang C, You Y, Chen XP et al. 2013. C-type lectin receptors Dectin-3 and Dectin-2 form a heterodimeric pattern-recognition receptor for host defense against fungal infection. Immunity 39: 324-34

59. Jouault T, Ibata-Ombetta S, Takeuchi O, Trinel PA, Sacchetti P et al. 2003. Candida albicans phospholipomannan is sensed through toll-like receptors. J Infect Dis 188: 165-72

60. Shoham S, Huang C, Chen JM, Golenbock DT, Levitz SM. 2001. Toll-like receptor 4 mediates intracellular signaling without TNF-alpha release in response to Cryptococcus neoformans polysaccharide capsule. $J$ Immunol 166: 4620-6

61. van de Veerdonk FL, Marijnissen RJ, Kullberg BJ, Koenen HJ, Cheng SC et al. 2009. The macrophage mannose receptor induces IL-17 in response to Candida albicans. Cell Host Microbe 5: 329-40

62. Bi L, Gojestani S, Wu W, Hsu YM, Zhu J et al. 2010. CARD9 mediates dectin-2-induced IkappaBalpha kinase ubiquitination leading to activation of NF-kappaB in response to stimulation by the hyphal form of Candida albicans. J Biol Chem 285: 25969-77

63. Sato K, Yang XL, Yudate T, Chung JS, Wu J et al. 2006. Dectin-2 is a pattern recognition receptor for fungi that couples with the Fc receptor gamma chain to induce innate immune responses. J Biol Chem 281: 38854-66

64. Robinson MJ, Osorio F, Rosas M, Freitas RP, Schweighoffer E, Gross O, Verbeek JS, Ruland J, Tybulewicz V, Brown GD, Moita LF, Taylor PR, Reis e Sousa C. 2009. Dectin-2 is a Syk-coupled pattern recognition receptor crucial for Th17 responses to fungal infection. $J$ ExpMed 206: 2037-51 
65. Saijo S, Ikeda S, Yamabe K, Kakuta S, Ishigame H et al. 2010. Dectin-2 recognition of alpha-mannans and induction of Th17 cell differentiation is essential for host defense against Candida albicans. Immunity 32: 68191

66. Cambi A, Gijzen K, de Vries l J, Torensma R, Joosten B et al. 2003. The C-type lectin DC-SIGN (CD209) is an antigen-uptake receptor for Candida albicans on dendritic cells. Eur J Immunol 33: 532-8

67. Gringhuis SI, den Dunnen J, Litjens M, van Het Hof B, van Kooyk Y et al. 2007. C-type lectin DC-SIGN modulates Toll-like receptor signaling via Raf-1 kinase-dependent acetylation of transcription factor NFkappaB. Immunity 26: 605-16

68. Serrano-Gomez D, Dominguez-Soto A, Ancochea J, Jimenez-Heffernan JA, Leal JA et al. 2004. Dendritic cellspecific intercellular adhesion molecule 3-grabbing nonintegrin mediates binding and internalization of Aspergillus fumigatus conidia by dendritic cells and macrophages. J Immunol 173: 5635-43

69. Wells CA, Salvage-Jones JA, Li X, Hitchens K, Butcher S et al. 2008. The macrophage-inducible C-type lectin, mincle, is an essential component of the innate immune response to Candida albicans. J Immunol 180: 7404-13

70. Yamasaki S, Matsumoto M, Takeuchi O, Matsuzawa T, Ishikawa E et al. 2009. C-type lectin Mincle is an activating receptor for pathogenic fungus, Malassezia. Proc Natl Acad Sci U S A 106: 1897-902

71. Ishikawa T, Itoh F, Yoshida S, Saijo S, Matsuzawa T et al. 2013. Identification of distinct ligands for the Ctype lectin receptors Mincle and Dectin-2 in the pathogenic fungus Malassezia. Cell Host Microbe 13: 477-88

72. Wevers BA, Kaptein TM, Zijlstra-Willems EM, Theelen B, Boekhout T et al. 2014. Fungal engagement of the C-type lectin mincle suppresses dectin-1-induced antifungal immunity. Cell Host Microbe 15: 494-505

73. Crameri R, Garbani M, Rhyner C, Huitema C. 2014. Fungi: the neglected allergenic sources. Allergy 69: 17685

74. Wills-Karp M, Nathan A, Page K, Karp CL. 2010. New insights into innate immune mechanisms underlying allergenicity. Mucosal Immunol 3: 104-10

75. Kouzaki H, O'Grady SM, Lawrence CB, Kita H. 2009. Proteases induce production of thymic stromal lymphopoietin by airway epithelial cells through protease-activated receptor-2. J Immunol 183: 1427-34

76. Kauffman HF, Tomee JF, van de Riet MA, Timmerman AJ, Borger P. 2000. Protease-dependent activation of epithelial cells by fungal allergens leads to morphologic changes and cytokine production. $J$ Allergy Clin Immunol 105: 1185-93

77. Leino MS, Loxham M, Blume C, Swindle EJ, Jayasekera NP et al. 2013. Barrier disrupting effects of Alternaria alternata extract on bronchial epithelium from asthmatic donors. PLoS One 8: e71278

78. Matsuwaki Y, Wada K, Moriyama H, Kita H. 2011. Human eosinophil innate response to Alternaria fungus through protease-activated receptor-2. Int Arch Allergy Immunol 155 Suppl 1: 123-8

79. Ossovskaya VS, Bunnett NW. 2004. Protease-activated receptors: contribution to physiology and disease. Physiol Rev 84: 579-621

80. Seltzer JM, Fedoruk MJ. 2007. Health effects of mold in children. Pediatr Clin North Am 54: 309-33, viii-ix

81. Wu F, Groopman JD, Pestka JJ. 2014. Public health impacts of foodborne mycotoxins. Annu Rev Food Sci Technol 5: 351-72

82. Bondy GS, Pestka JJ. 2000. Immunomodulation by fungal toxins. J Toxicol Environ Health B Crit Rev 3: 10943

83. Islam MR, Roh YS, Cho A, Kim J, Kim JH et al. 2012. Immune modulatory effects of the foodborne contaminant citrinin in mice. Food Chem Toxicol 50: 3537-47

84. Schutze N, Lehmann I, Bonisch U, Simon JC, Polte T. 2010. Exposure to mycotoxins increases the allergic immune response in a murine asthma model. Am J Respir Crit Care Med 181: 1188-99

85. Pestka JJ, Smolinski AT. 2011. Deoxynivalenol: Toxicology and Potential Effects on Humans. J Toxicol Environ Health, Part B 8: 39-69

86. Wang YC, Deng JL, Xu SW, Peng X, Zuo ZC et al. 2012. Effects of zearalenone on IL-2, IL-6, and IFNgamma mRNA levels in the splenic lymphocytes of chickens. ScientificWorldJournal 2012: 567327

87. Pistol G, Gras M, Marin DE, Tabuc C, Taranu I. 2013. Zearalenone induces alterations of hepatic immune responses by modulation of pro-inflammatory cytokines and matrix metalloproteinase gene expression. In 6th International Workshop on Immunonutrition, ed. PotN Society, pp. E2. Palma de Mallorca 
88. Stoev SD, Gundasheva D, Zarkov I, Mircheva T, Zapryanova D et al. 2012. Experimental mycotoxic nephropathy in pigs provoked by a mouldy diet containing ochratoxin A and fumonisin B1. Exp Toxicol Pathol 64: 733-41

89. Pieckova E. 2012. Adverse health effects of indoor moulds. Arh Hig Rada Toksikol 63: 545-9

90. Korpi A, Jarnberg J, Pasanen AL. 2009. Microbial volatile organic compounds. Crit Rev Toxicol 39: 139-93

| 91. Matysik S, Herbarth O, Mueller A. 2008. Determination of volatile metabolites originating from mould growth on wall paper and synthetic media. J Microbiol Methods 75: 182-7

92. Inamdar AA, Bennett JW. 2014. A common fungal volatile organic compound induces a nitric oxide mediated inflammatory response in Drosophila melanogaster. Sci Rep 4: 3833

93. Hargreave FE, Nair P. 2009. The definition and diagnosis of asthma. Clin Exp Allergy 39: 1652-8

94. Denning DW, Pashley C, Hartl D, Wardlaw A, Godet C et al. 2014. Fungal allergy in asthma-state of the art and research needs. Clin Transl Allergy 4: 14

95. Cai GH, Hashim JH, Hashim Z, Ali F, Bloom E et al. 2011. Fungal DNA, allergens, mycotoxins and associations with asthmatic symptoms among pupils in schools from Johor Bahru, Malaysia. Pediatr Allergy Immunol 22: 290-7

96. Zubairi AB, Azam I, Awan S, Zafar A, Imam AA. 2014. Association of airborne Aspergillus with asthma exacerbation in Southern Pakistan. Asia Pacific allergy 4: 91-8

97. Simon-Nobbe B, Denk U, Poll V, Rid R, Breitenbach M. 2008. The spectrum of fungal allergy. Int Arch Allergy Immunol 145: 58-86

98. Eduard W. 2009. Fungal spores: a critical review of the toxicological and epidemiological evidence as a basis for occupational exposure limit setting. Crit Rev Toxicol 39: 799-864

99. Hansel TT, Johnston SL, Openshaw PJ. 2013. Microbes and mucosal immune responses in asthma. Lancet 381: 861-73

100. Deckers J, Branco Madeira F, Hammad H. 2013. Innate immune cells in asthma. Trends Immunol 34: 540-7

101. Bartemes KR, Kephart GM, Fox SJ, Kita H. 2014. Enhanced innate type 2 immune response in peripheral blood from patients with asthma. J Allergy Clin Immunol 134: 671-8 e4

102. Manni ML, Robinson KM, Alcorn JF. 2014. A tale of two cytokines: IL-17 and IL-22 in asthma and infection. Expert Rev Respir Med 8: 25-42

103. McAleer JP, Kolls JK. 2014. Directing traffic: IL-17 and IL-22 coordinate pulmonary immune defense. Immunol Rev 260: 129-44

104. Chowdhary A, Agarwal K, Kathuria S, Gaur SN, Randhawa HS, Meis JF. 2014. Allergic bronchopulmonary mycosis due to fungi other than Aspergillus: a global overview. Crit Rev Microbiol 40: 30-48

105. Agarwal R. 2009. Allergic bronchopulmonary aspergillosis. Chest 135: 805-26

106. Jat KR, Walia DK, Khairwa A. 2013. Anti-IgE therapy for allergic bronchopulmonary aspergillosis in people with cystic fibrosis. Cochrane Database Syst Rev 9: CD010288

107. Knutsen AP. 2011. Immunopathology and immunogenetics of allergic bronchopulmonary aspergillosis. $J$ Allergy (Cairo) 2011: 785983

108. Chakrabarti A, Denning DW, Ferguson BJ, Ponikau J, Buzina W et al. 2009. Fungal rhinosinusitis: a categorization and definitional schema addressing current controversies. Laryngoscope 119: 1809-18

109. Callejas CA, Douglas RG. 2013. Fungal rhinosinusitis: what every allergist should know. Clin Exp Allergy 43: 835-49

110. Hamilos DL. 2014. Host-microbial interactions in patients with chronic rhinosinusitis. J Allergy Clin Immunol 133: $640-53$ e4

111. Glass D, Amedee RG. 2011. Allergic fungal rhinosinusitis: a review. Ochsner J 11: 271-5

112. Kern EB, Sherris D, Stergiou AM, Katz LM, Rosenblatt LC et al. 2007. Diagnosis and treatment of chronic rhinosinusitis: focus on intranasal Amphotericin B. Ther Clin Risk Manag 3: 319-25

113. Tang P, Mohan S, Sigler L, Witterick I, Summerbell R et al. 2003. Allergic fungal sinusitis associated with Trichoderma longibrachiatum. J Clin Microbiol 41: 5333-6

114. Gupta AK, Shah N, Kameswaran N, Rai D, D.N. J, Chopra H et al. 2012. Allergic fungal rhinosinusitis. Clinical rhinology: an International Journal 5: 72-86

115. Cavanna C, Seminari E, Pusateri A, Mangione F, Lallitto F et al. 2014. Allergic fungal rhinosinusitis due to Curvularia lunata. New Microbiol 37: 241-5 
116. Bakhshaee M, Fereidouni M, Mohajer MN, Majidi MR, Azad FJ et al. 2013. The prevalence of allergic fungal rhinosinusitis in sinonasal polyposis. Eur Arch Otorhinolaryngol 270: 3095-8

117. Ferguson BJ, Barnes L, Bernstein JM, Brown D, Clark CE, 3rd et al. 2000. Geographic variation in allergic fungal rhinosinusitis. Otolaryngol Clin North Am 33: 441-9

118. Montone KT, Livolsi VA, Feldman MD, Palmer J, Chiu AG et al. 2012. Fungal rhinosinusitis: a retrospective microbiologic and pathologic review of 400 patients at a single university medical center. Int $J$ Otolaryngol 2012: 684835

119. Mjosberg JM, Trifari S, Crellin NK, Peters CP, van Drunen CM et al. 2011. Human IL-25- and IL-33responsive type 2 innate lymphoid cells are defined by expression of CRTH2 and CD161. Nat Immunol 12: 1055-62

120. Selman M. 2004. Hypersensitivity pneumonitis: a multifaceted deceiving disorder. Clin Chest Med 25: 531-47, vi

121. Solaymani-Dodaran M, West J, Smith C, Hubbard R. 2007. Extrinsic allergic alveolitis: incidence and mortality in the general population. QJM 100: 233-7

122. Bourke SJ, Dalphin JC, Boyd G, McSharry C, Baldwin CI, Calvert JE. 2001. Hypersensitivity pneumonitis: current concepts. Eur Respir J Suppl 32: 81s-92s

123. Kurup VP, Zacharisen MC, Fink JN. 2006. Hypersensitivity pneumonitis. Indian J Chest Dis Allied Sci 48: $115-28$

124. Ye Q, Nakamura S, Sarria R, Costabel U, Guzman J. 2009. Interleukin 12, interleukin 18, and tumor necrosis factor alpha release by alveolar macrophages: acute and chronic hypersensitivity pneumonitis. Ann Allergy Asthma Immunol 102: 149-54

125. Barrera L, Mendoza F, Zuniga J, Estrada A, Zamora AC et al. 2008. Functional diversity of T-cell subpopulations in subacute and chronic hypersensitivity pneumonitis. Am J Respir Crit Care Med 177: 44-55

126. Bhan U, Newstead MJ, Zeng X, Podsaid A, Goswami M et al. 2013. TLR9-dependent IL-23/IL-17 is required for the generation of Stachybotrys chartarum-induced hypersensitivity pneumonitis. J Immunol 190: 349-56

127. Deschamps F, Foudrinier F, Dherbecourt V, Mas P, Prevost E, Legrele AM, Bellier S, Toubas D. 2003. Respiratory diseases in French cork workers. Inhal Toxicol 15: 1479-86

128. Knutsen AP, Bush RK, Demain JG, Denning DW, Dixit A et al. 2012. Fungi and allergic lower respiratory tract diseases. J Allergy Clin Immunol 129: 280-91; quiz 92-3

129. Von Essen S, Fryzek J, Nowakowski B, Wampler M. 1999. Respiratory symptoms and farming practices in farmers associated with an acute febrile illness after organic dust exposure. Chest 116: 1452-8

130. Perry LP, Iwata M, Tazelaar HD, Colby TV, Yousem SA. 1998. Pulmonary mycotoxicosis: a clinicopathologic study of three cases. Mod Pathol 11: 4

131. Flemming J, Hudson B, Rand TG. 2004. Comparison of inflammatory and cytotoxic lung responses in mice after intratracheal exposure to spores of two different Stachybotrys chartarum strains. Toxicol Sci 78: 267-75

132. Von Essen SG, Andersen CI, Smith LM. 2005. Organic dust toxic syndrome: A noninfectious febrile illness after exposure to the hog barn environment. Journal of Swine Health and Production 13: 273-5

133. Morath SU, Hung R, Bennett JW. 2012. Fungal volatile organic compounds: A review with emphasis on their biotechnological potential. Fungal Biol Rev 26: 73-83

134. Andersen B, Frisvad JC, Sondergaard I, Rasmussen IS, Larsen LS. 2011. Associations between fungal species and water-damaged building materials. Appl Environ Microbiol 77: 4180-8

135. Brewer JH, Thrasher JD, Hooper D. 2014. Chronic illness associated with mold and mycotoxins: is naso-sinus fungal biofilm the culprit? Toxins (Basel) 6: 66-80

136. Hooper DG, Bolton VE, Guilford FT, Straus DC. 2009. Mycotoxin detection in human samples from patients exposed to environmental molds. Int J Mol Sci 10: 1465-75

137. Sardi Jde C, Pitangui Nde S, Rodriguez-Arellanes G, Taylor ML, Fusco-Almeida AM et al. 2014. Highlights in pathogenic fungal biofilms. Rev Iberoam Micol 31: 22-9

138. Thrasher JD, Gray MR, Kilburn KH, Dennis DP, Yu A. 2012. A water-damaged home and health of occupants: a case study. J Environ Public Health 2012: 312836

139. Yike I, Rand TG, Dearborn DG. 2005. Acute inflammatory responses to Stachybotrys chartarum in the lungs of infant rats: time course and possible mechanisms. Toxicol Sci 84: 408-17

140. Claeson AS, Sandstrom M, Sunesson AL. 2007. Volatile organic compounds (VOCs) emitted from materials collected from buildings affected by microorganisms. J Environ Monit 9: 240-5 
141. Sahlberg B, Gunnbjornsdottir M, Soon A, Jogi R, Gislason T et al. 2013. Airborne molds and bacteria, microbial volatile organic compounds (MVOC), plasticizers and formaldehyde in dwellings in three North European cities in relation to sick building syndrome (SBS). Sci Total Environ 444: 433-40

142. Walinder R, Ernstgard L, Norback D, Wieslander G, Johanson G. 2008. Acute effects of 1-octen-3-ol, a microbial volatile organic compound (MVOC)--an experimental study. Toxicol Lett 181: 141-7

143. WHO. 2009. Guidelines for indoor air quality: dampness and mould

144. Smeekens SP, van de Veerdonk FL, Kullberg BJ, Netea MG. 2013. Genetic susceptibility to Candida infections. EMBO Mol Med 5: 805-13

145. Wójtowicz A, Bochud PY. In press. Host genetics of invasive Aspergillus and Candida infections. Semin Immunopathol

146. Mantovani A, Valentino S, Gentile S, Inforzato A, Bottazzi B et al. 2013. The long pentraxin PTX3: a paradigm for humoral pattern recognition molecules. Ann N Y Acad Sci 1285: 1-14

147. Agarwal R, Khan A, Aggarwal AN, Gupta D. 2012. Link between CFTR mutations and ABPA: a systematic review and meta-analysis. Mycoses 55: 357-65

148. Vaid M, Kaur S, Sambatakou H, Madan T, Denning DW et al. 2007. Distinct alleles of mannose-binding lectin (MBL) and surfactant proteins A (SP-A) in patients with chronic cavitary pulmonary aspergillosis and allergic bronchopulmonary aspergillosis. Clin Chem Lab Med 45: 183-6

149. Brouard J, Knauer N, Boelle PY, Corvol H, Henrion-Caude A et al. 2005. Influence of interleukin-10 on Aspergillus fumigatus infection in patients with cystic fibrosis. J Infect Dis 191: 1988-91

150. Carvalho A, Pasqualotto AC, Pitzurra L, Romani L, Denning DW et al. 2008. Polymorphisms in toll-like receptor genes and susceptibility to pulmonary aspergillosis. J Infect Dis 197: 618-21

151. The Nordic Expert Group for Criteria Documentation of Health Risk from Chemicals. Eduard W. 2006. Fungal spores. The National Institute for Working Life

152. Kokkonen M, Ojala L, Parikka P, Jestoi M. 2010. Mycotoxin production of selected Fusarium species at different culture conditions. Int J Food Microbiol 143: 17-25

153. Hueza IM, Raspantini PC, Raspantini LE, Latorre AO, Gorniak SL. 2014. Zearalenone, an estrogenic mycotoxin, is an immunotoxic compound. Toxins (Basel) 6: 1080-95

154. Berek L, Petri IB, Mesterhazy A, Teren J, Molnar J. 2001. Effects of mycotoxins on human immune functions in vitro. Toxicol In Vitro 15: 25-30

155. Bracarense AP, Lucioli J, Grenier B, Drociunas Pacheco G, Moll WD et al. 2012. Chronic ingestion of deoxynivalenol and fumonisin, alone or in interaction, induces morphological and immunological changes in the intestine of piglets. Br J Nutr 107: 1776-86

156. Ghosh S, Hoselton SA, Dorsam GP, Schuh JM. 2013. Eosinophils in fungus-associated allergic pulmonary disease. Front Pharmacol 4: 8

157. Cosmi L, Liotta F, Maggi E, Romagnani S, Annunziato F. 2011. Th17 cells: new players in asthma pathogenesis. Allergy 66: 989-98

158. Knutsen AP, Vijay HM, Kariuki B, Santiago LA, Graff R, Wofford JD et al. 2010. Association of IL-4RA single nucleotide polymorphisms, HLA-DR and HLA-DQ in children with Alternaria-sensitive moderatesevere asthma. Clinical and molecular allergy 8: 5

159. Porter PC, Lim DJ, Maskatia ZK, Mak G, Tsai CL et al. 2014. Airway surface mycosis in chronic TH2associated airway disease. J Allergy Clin Immunol 134: 325-31 e9

160. Schubert MS, Hutcheson PS, Graff RJ, Santiago L, Slavin RG. 2004. HLA-DQB1 *03 in allergic fungal sinusitis and other chronic hypertrophic rhinosinusitis disorders. J Allergy Clin Immunol 114: 1376-83

161. Simonian PL, Roark CL, Wehrmann F, Lanham AK, Diaz del Valle F et al. 2009. Th17-polarized immune response in a murine model of hypersensitivity pneumonitis and lung fibrosis. $J$ Immunol 182: 657-65

162. Millon L, Roussel S, Rognon B, Quadroni M, Salamin K et al. 2012. Aspergillus species recombinant antigens for serodiagnosis of farmer's lung disease. J Allergy Clin Immunol 130: 803-5 e6

163. Reboux G, Reiman M, Roussel S, Taattola K, Millon L et al. 2006. Impact of agricultural practices on microbiology of hay, silage and flour on Finnish and French farms. Ann Agric Environ Med 13: 267-73

164. Jeffery PK. 2001. Lymphocytes, chronic bronchitis and chronic obstructive pulmonary disease. Novartis Foundation symposium 234: 149-61; discussion 61-8 
165. Rivoire B, Attucci S, Anthonioz P, Carre P, Lemarie E et al. 2001. Occupational acute lung injury due to Alternaria alternata: early stage of organic dust toxic syndrome requires no corticosteroids. Intensive Care Med 27: 1236-7 
Table 1. Fungal families producing mycotoxins and microbial volatile organic components (MVOCs).

\begin{tabular}{lllc}
\hline Fungal family & Mycotoxin & MVOCs & Reference \\
\hline Aspergillus & Aflatoxin, citrinin, gliotoxin, ochratoxin, patulin & Yes & {$[151]$} \\
Fusarium & $\begin{array}{l}\text { Deoxynivalenol [DON], 3-acetyl deoxynivalenol [3-ADON], } \\
\text { fumonisin B1 [FB-1], fusarenon-X, nivalenol [NIV], T-2 toxin, }\end{array}$ & & {$[152-154]$} \\
& zearalenone [ZEA] & & \\
Penicillium & Citrinin, gliotoxin, ochratoxin, patulin & Yes & {$[83,84,155]$} \\
\hline
\end{tabular}




\begin{tabular}{|c|c|c|c|c|c|c|}
\hline $\begin{array}{l}\text { Allergic / } \\
\text { non allergic }\end{array}$ & Pathology & $\begin{array}{l}\text { Hypersensitivity } \\
\text { reaction }\end{array}$ & Ig response & Cellular response & Principal fungus & Genetic risk factors \\
\hline \multirow[t]{4}{*}{ Allergic } & Asthma & Type I & $\begin{array}{l}\text { IgE (atopic } \\
\text { asthma); non- } \\
\text { IgE (nonatopic } \\
\text { asthma) }\end{array}$ & $\begin{array}{l}\text { Th2 with eosinophilia } \\
\text { [156]; Th17 with } \\
\text { neutrophilia [102, } \\
\text { 157] }\end{array}$ & $\begin{array}{l}\text { Alternaria, Aspergillus, Aureobasidium, } \\
\text { Cladosporium, Epicoccum, } \\
\text { Helminthosporium and Penicillium [97] }\end{array}$ & $\begin{array}{l}\text { IL4RA and HLA-DQ in children of mixed } \\
\text { ethnicity with Alternaria -sensitive asthma } \\
\text { [158] }\end{array}$ \\
\hline & АВРА/АВРМ & Type I, III, IV & $\begin{array}{l}\text { IgE and/or IgG, } \\
\text { IgA }\end{array}$ & $\begin{array}{l}\text { Th2, eosinophilia, T } \\
\text { cells }[104,107]\end{array}$ & $\begin{array}{l}\text { A. fumigatus, C. albicans, Bipolaris } \\
\text { spp., Shyzophyllum commune, } \\
\text { Curvularia spp. [104] }\end{array}$ & $\begin{array}{l}\text { HLA-DR, HLA-DQ, IL4RA, IL10 and } \\
\text { TLR9 in mixed populations from USA, } \\
\text { France and Germany and UK; SPA2 and } \\
\text { CFTR in Caucasians }[107,147-150]\end{array}$ \\
\hline & AFRS & Type I & $\operatorname{IgE}$ & $\begin{array}{l}\text { Th2 with eosinophilia } \\
\text { [159] (Th17) [24] }\end{array}$ & $\begin{array}{l}\text { Aspergillus spp., Bipolaris spicifera, } \\
\text { Curvularia lunata, A. alternata, } \\
\text { Cladosporium spp., Trichoderma } \\
\text { longibrachiatum [109, 113-115] }\end{array}$ & $\begin{array}{l}\text { HLA-DQ in Hispanic and White Americans } \\
\text { [160] }\end{array}$ \\
\hline & $\mathrm{HP}$ & Type III, IV & IgG & $\begin{array}{l}\text { Th1 (acute, subacute), } \\
\text { Th2 (chronic) and } \\
\text { Th17 (mouse model), } \\
\text { neutrophilia, } \\
\text { lymphocytosis [124, } \\
\text { 125, 126, 161] }\end{array}$ & $\begin{array}{l}\text { Aspergillus, Alternaria, Aureobasidium, } \\
\text { Cladosporium, Cryptococcus, } \\
\text { Epicoccum, Eurotium amstelodami, } \\
\text { Fusarium, Lichtheimia corymbifera, } \\
\text { Paecilomyces, Penicillium, } \\
\text { Trichosporon, Wallebia sebi [162, 163] }\end{array}$ & 1 \\
\hline \multirow[t]{3}{*}{ Non allergic } & Chronic bronchitis & & & Neutrophilia [164] & A. fumigatus, $P$. frequentans $[127,128]$ & 1 \\
\hline & ODTS & & & $\begin{array}{l}\text { Neutrophilia, } \\
\text { cytokines }[132,165]\end{array}$ & $\begin{array}{l}\text { A. fumigatus, Penicillium spp., A. } \\
\text { nidulans [130] }\end{array}$ & 1 \\
\hline & $\begin{array}{l}\text { Chronic } \\
\text { mycotoxicosis }\end{array}$ & & & Cytokines [139] & $\begin{array}{l}\text { Penicillium, Aspergilus, Chaetomium, } \\
\text { Acremonium, Ulocladiums, } \\
\text { Cladosporium, Mucor, Trichoderma, } \\
\text { Alternaria, Sporothrix, Rhodotorula, } \\
\text { Rhizopus, Stachybotrys, } \\
\text { Calcarisporium, Scopulariopsis and } \\
\text { Fusarium spp. [131, 134] }\end{array}$ & 1 \\
\hline
\end{tabular}

$3 \quad{ }^{1}$ No unambiguous association reported 